\title{
'Longhua' Lonicera
}

Jianjun Chen ${ }^{1}$

Hunan Academy of Forestry, 658 South Shaoshan Road, Changsha, Hunan 410004, China; Hunan Key Laboratory for Breeding of Clonally Propagated Forest Trees, 658 South Shaoshan Road, Changsha, Hunan 410004, China; and University of Florida, IFAS, Mid-Florida Research and Education Center, 2725 S. Binion Road, Apopka, FL 32703

\section{Xiaoming Wang ${ }^{1}$, Neng Cai, Yongxin Li, Huijie Zeng, and Zhongquan Qiao \\ Hunan Academy of Forestry, 658 South Shaoshan Road, Changsha, Hunan 410004, China; and Hunan Key Laboratory for Breeding of Clonally Propagated Forest Trees, 658 South Shaoshan Road, Changsha, Hunan 410004, China}

Additional index words. chlorogenic acid, honeysuckle, Lonicera macranthoides, medicinal plants, ornamental plants

The genus of Lonicera L., commonly referred to as honeysuckle, has $\approx 180$ species of deciduous or evergreen, bushy, candent, twining, or creeping shrubs distributed in Asia, Europe, and North America (Huxley, 1992). Dried flowers and buds of honeysuckles are known as "Jinyinhua" in Chinese or flos lonicerae, which is one of the most popular herbs of traditional Chinese medicine (Shang et al., 2011). Flos lonicerae contains a series of compounds including essential oils, organic acids, flavones, saponins, and iridoids (Lee et al., 1998; Palacios et al., 2002). Because of the variation among species and even cultivars in the chemical compounds, the Chinese Pharmacopoeia (Committee for the Pharmacopoeia of PR China, 2010) has used the content of 5-O-caffeoylquinic acid or chlorogenic acid (CGA) as the indicator compound for the evaluation of the quality of flos lonicerae (Shang et al., 2011). CGA has been reported to suppress $N$-nitrosating reactions and inhibit hepatic glucose 6-phosphatase, which is a significant factor in the abnormal diabetic state (Arion et al., 1997; Yang et al., 2004). CGA also has strong antiviral activity against adenoassociated 3 and 7 viruses, coxsackie B3 and B5 viruses, and respiratory syncytia virus (Hu et al., 2001).

As a result of the increasing recognition of its pharmaceutical value, there have been increasing activities in the selection and production of honeysuckle plants with high CGA content in China (Wang et al., 2004, 2009; Yuan et al., 2012). Lonicera macranthoides Hands.-Mazz. is a species native to China

Received for publication 5 Feb. 2013. Accepted for publication 5 Mar. 2013.

This study was supported in part by the Special Fund for National Forestry Research in the Public Interest 201104023 and the Changsha City Science and Technology Key Project Fund K1003313-21.

${ }^{1}$ To whom reprint requests should be addressed; e-mailjjchen@ufl.edu orwxm1964@163.com.
(Xu and Wang, 1988) and has been found to contain CGA concentrations up to $4.5 \%$ compared with commonly used L. japonica L. with a range from $2.2 \%$ to $2.5 \%$ (Zhou and Tong, 2003). Wang et al. (2004) isolated three naturally occurring mutants: 'Jincuilei', 'Yincuilei', and 'Baiyun' of $L$. macranthoides from Hunan Province, China, which had CGA contents of 5.92\%, 5.83\%, and $6.97 \%$, respectively, compared with $4.33 \%$ in their parental plants. Here we report 'Longhua', another selection from Lonicera macranthoides.

\section{Origin}

Lonicera macranthoides is mainly distributed in Hunan, Guizhou, Guangxi, and Sichuan Provinces in China. The plant seldom produces seeds in its natural habitat, and plants are propagated through cutting or grafting. A mutant plant with abundant large flowers that never opened was discovered in Longhui County, Hunan Province in 2005. The plant was propagated by cutting and grafting in 2006 and evaluated for five years. The mutant was stable over the last six years and named 'Longhua' in accordance with the International Code of Nomenclature for Cultivated Plants (Brickell et al., 2009). A specimen of the cultivar has been deposited at the Experimental Station in Longhui County as a cultivar standard.

\section{Description}

'Longhua' is a shrub with a dome-shaped crown (Fig. 1A). Plant height is over $1.5 \mathrm{~m}$ and canopy diameter of 4 to $5 \mathrm{~m}$. Leaves are simple, opposite, ovate to oblong with a round base and acuminate apex. The upper leaf surface is azure green, whereas the underside is yellowish green. The mean length of mature leaves is $\approx 11.2 \mathrm{~cm}$ with a width of $\approx 5.4 \mathrm{~cm}$

The young alabastrum is green and clustered axillarily or at the terminal (Fig. 1B).
The corolla is tubular; as it becomes mature, the upper tube expands much more than the base portion. Mature corollas are clavate, curved slightly, indehiscent, and yellowish white. The mean length of a mature flower is $\approx 5.94 \mathrm{~cm}$, apex diameter is $\approx 3.20 \mathrm{~mm}$, and base diameter is $\approx 1.54 \mathrm{~mm}$. A branch can bear up to seven clusters of flowers in axillary or in terminal spikes. Mean flower numbers are more than 20 in each cluster arranged in cymes or racemes. The calyx is green without woolly hair in the tube. The flowers never open and plants have not been seen bearing any berries.

\section{Culture and Performance}

Propagation of 'Longhua' is primarily through grafting and cutting. In vitro culture has not been well established. Both the parental L. macranthoides and L. japonica have been used as rootstocks for grafting. Grafted plants can flower in the second year if the rootstocks have a height over $50 \mathrm{~cm}$. Cuttings can be either single eye or multiple eyes and should be made from plants less than three years old. Rooted cuttings can grow up to $1.5 \mathrm{~m}$ in three years and plants then flower. 'Longhua' is highly adaptable to different soil types with $\mathrm{pH}$ ranging from 5.5 to 7.5 and is able to grow in mountainous areas, hilly countries, or plains. Plants should be transplanted $2.1 \mathrm{~m}$ apart $(\approx 2250$ plant per hectare) and fertilized with $0.15 \mathrm{~kg}$ of $\mathrm{N}-\mathrm{P}_{2} \mathrm{O}_{5}-\mathrm{K}_{2} \mathrm{O}$ and $0.1 \mathrm{~kg}$ of magnesium annually. Application of composted organic fertilizers at $2 \mathrm{~kg}$ per plant is highly recommended each spring after pruning.

Lonicera 'Longhua' in Hunan Province sprout in late February with a temperature above $10{ }^{\circ} \mathrm{C}$. The first flower appears in middle May; flowering peak time is early July. The fresh weight per 1000 flowers is $151 \mathrm{~g}$. To determine flower yield and CGA content of 'Longhua', two field trials were conducted in different locations of Longhui County, Hunan Province. Grafted 'Longhua' was compared with parental L. macranthoides as well as previously selected cultivars Jincuilei, Yincuili, and Baiyun that were also graft-propagated at the same time as 'Longhua'. Flower sizes, flower yield, and CGA contents were determined; data were analyzed by analysis of variance (SAS GLM; SAS Institute, Cary, NC), and mean separations were performed using Fisher's protected least significant differences at the $5 \%$ level. Results showed that 'Longhua' had a mean flower length of $5.94 \mathrm{~cm}$ and flower apex diameter of $3.20 \mathrm{~cm}$, which were significantly greater than the other tested cultivars (Table 1). Flowers harvested from the third year of plants were $1.55 \mathrm{~kg}$ per plant based on dry weight, which was higher than the parental plants and 'Yincuilei', comparable to 'Jincuilei' and 'Baiyun' (Table 1). Thus, a hectare of 'Longhua' could produce $\approx 3488 \mathrm{~kg}$ of dry flowers annually. The CGA content in dry flowers was $7.25 \%$; this was significantly greater than the other tested cultivars with the exception of 'Baiyun'. 

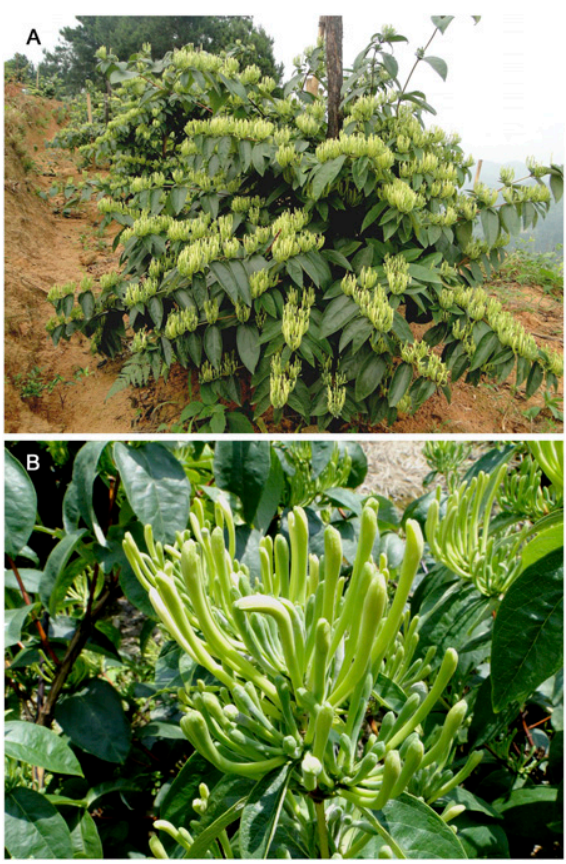

Fig. 1. Lonicera macranthoides 'Longhua' were grown in Longhui County, Hunan Province, China, with abundant flowers (A); as a mutant, the flowers of this cultivar never opened (B).

\section{Availability}

Limited numbers of rooted cuttings of Lonicera 'Longhua' are available for research purposes, which can be obtained from Xiaoming Wang, the Hunan Key Laboratory for Breeding of Clonally Propagated Forest Trees.

\section{Literature Cited}

Arion, W.J., W.K. Canfield, F.C. Ramos, P.W. Schindler, H. Burger, H. Hemmerle, G. Schubert,

Table 1. Flower characteristics, yield, and chlorogenic acid content of parental Lonicera macranthoides and cultivars of Longhua, Jincuilei, Yincuilei, and Baiyun selected from this species. ${ }^{2}$

\begin{tabular}{lcccccc}
\hline & $\begin{array}{c}\text { Flower } \\
\text { length }(\mathrm{cm})\end{array}$ & $\begin{array}{c}\text { Flower apex } \\
\text { diam }(\mathrm{mm})\end{array}$ & $\begin{array}{c}\text { Flower base } \\
\text { diam }(\mathrm{mm})\end{array}$ & $\begin{array}{c}\text { Flower open } \\
\text { or closed }\end{array}$ & $\begin{array}{c}\text { Flower yield } \\
\text { in dry wt } \\
\text { (kg/plant) }\end{array}$ & $\begin{array}{c}\text { Chlorogenic } \\
\text { acid content (\%) }\end{array}$ \\
\hline Parental plant & $3.93 \mathrm{~b}^{\mathrm{y}}$ & $2.41 \mathrm{~b}$ & $1.40 \mathrm{ab}$ & Open & $0.65 \mathrm{c}$ & $4.33 \mathrm{c}$ \\
Longhua & $5.94 \mathrm{a}$ & $3.20 \mathrm{a}$ & $1.54 \mathrm{a}$ & Closed & $1.55 \mathrm{a}$ & $7.25 \mathrm{a}$ \\
Jincuilei & $4.00 \mathrm{~b}$ & $2.50 \mathrm{~b}$ & $1.30 \mathrm{~b}$ & Closed & $1.50 \mathrm{a}$ & $5.92 \mathrm{~b}$ \\
Yincuilei & $4.20 \mathrm{~b}$ & $2.50 \mathrm{~b}$ & $1.50 \mathrm{a}$ & Closed & $1.16 \mathrm{~b}$ & $5.83 \mathrm{~b}$ \\
Baiyun & $3.90 \mathrm{~b}$ & $2.50 \mathrm{~b}$ & $1.60 \mathrm{a}$ & Partially open & $1.77 \mathrm{a}$ & $6.97 \mathrm{a}$ \\
\hline
\end{tabular}

${ }^{2}$ Measurements were taken from the three-year-old plants, and the data were the mean of 10 plants per cultivar.

${ }^{y}$ Different letters within a column represent significant difference at $P \leq 0.05$ by Fisher's protected least significant difference test.

P. Below, and A.W. Herling. 1997. Chlorogenic acid and hydroxynitrobenzaldehyde: New inhibitors of hepatic glucose 6-phosphatase. Arch. Biochem. Biophys. 339:315-322.

Brickell, C.D., C. Alexander, J.C. David, W.L.A. Hetterscheid, A.C. Leslie, V. Malecot, and X. Jin. 2009. International code of nomenclature for cultivated plants. 8th Ed. International Society for Horticultural Sciences, Scripta Horticulturae 10.

Committee for the Pharmacopoeia of PR China. 2010. Pharmacopoeia of PR China, Part I. China Medical Science and Technology Press, PR China [in Chinese].

Hu, K.J., K.X. Sun, and J.L. Wang. 2001. Inhibited effect of chlorogenic acid on virus in vitro. J. Harbin Med. Univ. 35:430-432 [in Chinese]

Huxley, A. 1992. The new royal horticultural society dictionary of gardening. Macmillan Press, London, UK.

Lee, S.J., K.H. Son, H.W. Chang, S.S. Kang, and H.P. Kim. 1998. Anti-inflammatory activity of Lonicera japonica. Phytochem. Rev. 12:445447.

Palacios, N., P. Christon, and M.J. Leech. 2002. Regeneration of Lonicera tatarica plants via adventitious organogenesis from cultured stem explants. Plant Cell Rep. 20:808-813.

Shang, X., H. Pan, M. Li, X. Miao, and H. Ding. 2011. Lonicera japonica Thunb.: Ethnopharmacology, phytochemistry and pharmacology of an important traditional Chinese medicine. J. Ethnopharmacol. 138:1-21.

Wang, X., J. Chen, Y. Li, Q. Nie, and J. Li. 2009. An efficient procedure for regeneration from leaf derived calluses of Lonicera Macranthoides 'Jincuilei', an important medicinal plant. HortScience 44:746-750.

Wang, X., J. Luo, and Q. Song. 2004. Breeding new cultivars of Lonicera macranthoides HandMazz. Hunan Forest Sci. Technol. 31:15-17 [in Chinese].

Xu, B. and J. Wang. 1988. Lonicera L., p. 143-259. In: Xu, B. (ed.). Flora reipublicae popularis sinicae. Science Press, Beijing, China.

Yang, H., B. Yuan, L. Li, H. Chen, and F. Li. 2004. HPLC determination of pharmacokinetics of chlorogenic acid in rabbit plasma after an oral dose of flos lonicerae extract. J. Chromatogr. Sci. 42:173-176.

Yuan, Y., Z. Wang, C. Jiang, X. Wang, and L. Huang. 2012. Exploiting genes and functional diversity of chlorogenic acid and luteolin biosyntheses in Lonicera japonica and their substitutes. Gene. doi: 10.1016/j.gene.2012. 09.051 .

Zhou, R. and Q. Tong. 2003. Comparative study on content of chlorogenic acid in Lonicera japonica and L. macranthoides. J. Chinese Med. Materials 26:399-400 [in Chinese]. 